\title{
Clinical and Angiographical Delayed Cerebral Vasospasms After Uncomplicated Surgical Clipping of Unruptured Intracranial Aneurysms: Illustrated Review and Two Case Reports
}

\author{
Rüptüre Olmamıs Intrakraniyal Anevrizmalarn Komplikasyonsuz \\ Cerrabi Klip Uygulamasından Sonra Klinik ve Anjiyografik Gecikmiş \\ Serebral Vazospazmlar: Şekillerle Gözden Geçirme ve İki Olgu Sunumu
}

Kuhyun YANG, Jae Sung AHN, Jung Cheol PARK, Do Hoon KWON, Byung Duk KWUN

Asan Medical Center, Neurological Surgery, Seoul, Republic of Korea

Corresponding Author: Jae Sung AHN / E-mail: jsahn@amc.seoul.kr

\begin{abstract}
From January 2007 to April 2012, we performed 2427 surgical clippings for unruptured intracranial aneurysms (UIAs). Among these patients, two cases showed symptomatic and angiographic cerebral vasospasm in the delayed post-operative period without a complicated event. Additionally, we reviewed four cases of delayed cerebral vasospasms following uncomplicated operations that were consistent with our inclusion criteria in the previous literature. The pathogenesis and characteristics of these rare occurrences are reviewed from our two cases and previous literature. For clipping of UIAs, it should be kept mind that neurological symptoms are caused by delayed cerebral vasospasm, and careful observation with proper conservative treatment are necessary to ensure favorable outcomes.
\end{abstract}

KEYWORDS: Cerebral vasospasm, Surgical clipping, Unruptured intracranial aneurysms (UIAs)

öz

Ocak 2007 ile Nisan 2012 arasında rüptüre olmamış intrakraniyal anevrizmalar (UIA'lar) için 2427 cerrahi klip uygulama işlemi yapıldı. İki hastada gecikmiş postoperatif dönemde komplikasyon olmadan semptomatik ve anjiyografik serebral vazospazm görüldü. Ayrıca önceki literatürdeki çalışmaya alma kriterlerimizle uyumlu olacak şekilde komplikasyonsuz ameliyatlar sonrasında dört gecikmiş serebral vazospazm olgusu gözden geçirildi. Bu nadir durumların patogenez ve özellikleri iki olgumuz ve önceki literatür kullanılarak gözden geçirilmektedir. UIA'ya klip uygulanması açısından nörolojik belirtilerin nedeninin gecikmiş serebral vazospazm olduğu ve olumlu sonuçlar sağlanması için uygun konservatif tedaviyle birlikte dikkatli bir gözlemin gerektiği unutulmamalıdır.

ANAHTAR SÖZCÜKLER: Serebral vazospazm, Cerrahi klip uygulama, Rüptüre olmamış intrakraniyal anevrizmalar (UIA'lar)

\section{INTRODUCTION}

Diffuse cerebral vasospasm is a clinical and angiographic condition frequently observed following subarachnoid hemorrhage (SAH) caused by the rupturing of an intracranial aneurysm (6). However, delayed cerebral vasospasms after uncomplicated operations on unruptured intracranial aneurysms have rarely been reported. Here, we report two such cases and review them in the context of four cases reported previously $(3,8,9)$. We analyzed the characteristics of all six patients and each aneurysm, clinical presentations, treatments, recovery and relationship to surgical factors. The results will contribute to the understanding of delayed vasospasms occurring after uncomplicated operations on unruptured intracranial aneurysms.
Our inclusion criteria were as follows: 1) No evidence of a ruptured aneurysm in pre-operative computed tomography (CT) images and intra-operative findings. 2) No intra-operative events, such as a rupturing aneurysm, direct mechanical vessel destruction or twisting of the vessel due to the clip. 3) No unusual finding in immediate post-operative CT images. 4) Delayed onset of vasospasm i.e. at least seven days postoperatively.

\section{CASE REPORT}

After reporting a non-specific headache, a 41-year old woman underwent a computed tomography (CT) scan and a transfemoral cerebral angiogram (TFCA). There was no evidence of subarachnoid hemorrhage (SAH) or other abnormal lesions in the CT. However, the TFCA showed an unruptured intracranial aneurysm (UIA) in the left internal 
carotid artery (ICA) bifurcation (Figure 1A). The patient underwent surgery through a left fronto-temporal craniotomy (via the pterional route). When the aneurysm was dissected, there was no evidence of SAH. The post-operative course for the patient was uneventful. Immediate post-operative pre-contrast CT (Figure 1B), CT angiography showed no abnormal lesions except the usual post-operative changes. The patient maintained a normal neurological condition and was discharged on the 7th post-operative day. On the 28th post-operative day, however, the patient developed right facial numbness, a decrease in the motor power of hand grasping movement (grade IV+) and a mild motor aphasia. Diffusion magnetic resonance images (MRI) showed high signal intensity in the left insular cortex (Figure 1C) and the TFCA revealed significant vasospasm of the left distal ICA in the $A 1$ and $M 1$ segments (Figure 1D). We performed a chemical angioplasty (with $8 \mathrm{mg}$ nicardipine) and treated the patient with hydration and anti-platelet drugs (aspirin). Her neurological condition was virtually normal by seven days after the chemical angioplasty. Afterwards, one month follow-up CT angiography showed marked improvement compared with the previous images. The patient did not show recurrence or any unusual event for 36 months after then.

\section{LITERATURE REVIEW}

Our literature search yielded several cases of delayed cerebral vasospasm occurring after an uncomplicated operation for the treatment of unruptured aneurysms. Only six patients had truly delayed nonhemorrhagic vasospasms after uncomplicated clipping of an UIA. The clinical data for the six patients are summarized in Table I. All six patients were female (21-61 years). The size of the aneurysm varied from 3 $\mathrm{mm}$ to $8 \mathrm{~mm}$, and there were no large aneurysms. Contrary to our expectations, small or medium sized aneurysms appear to be prone to delayed non-hemorrhagic vasospasms after uncomplicated clipping. Interestingly, half numbers of aneurysms were located in the distal ICA and the other half in the MCA bifurcation. Two distal ICA aneurysms were located on the left side. One distal ICA and all MCA bifurcation aneurysms were located on the right side. There were no aneurysms in the proximal ICA or more peripherally, such as in the anterior or posterior cerebral artery or the anterior communicating artery. Onset of vasospasm symptoms was delayed until at least 9 days following the operation. In two cases, the time of onset of symptoms was the 28th postoperative day. It is significant that vasospasms from subarachnoid hemorrhages tend to occur earlier. Aphasia and motor weakness were
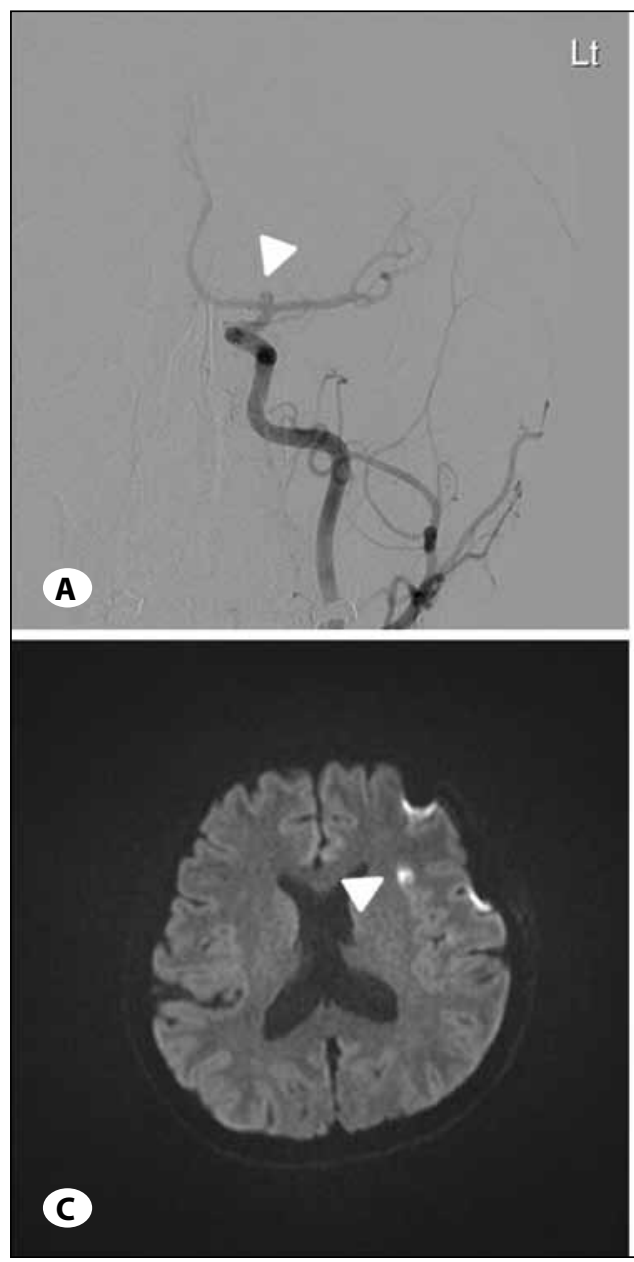
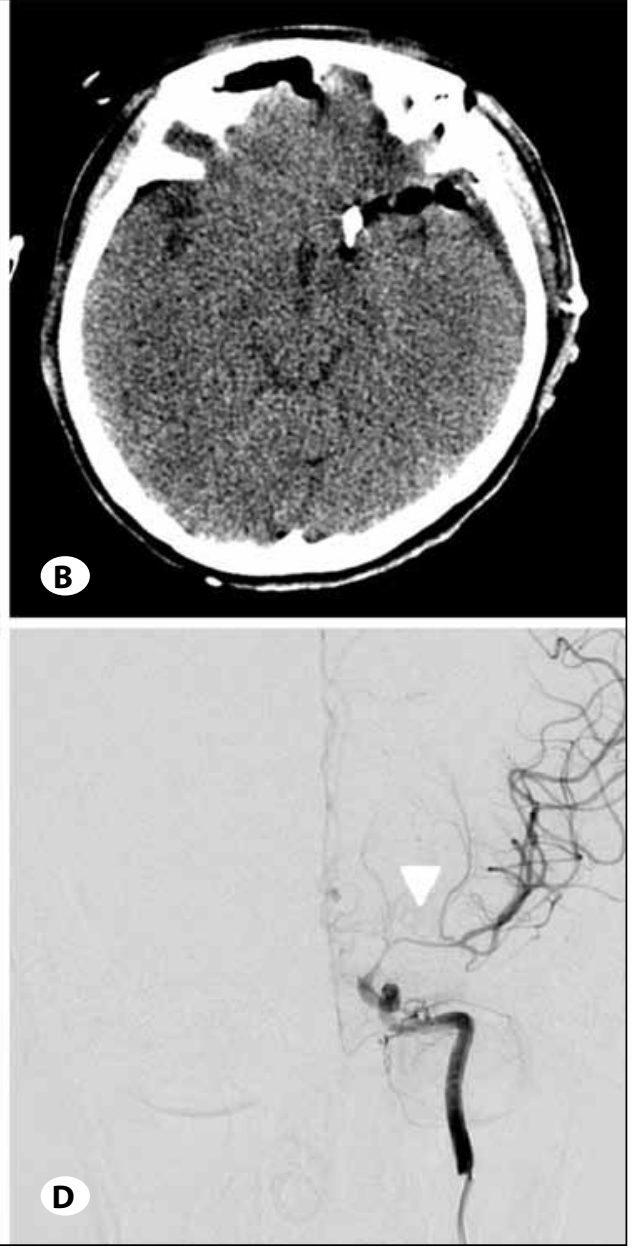

Figure 1: A) Preoperative transfemoral cerebral angiography (TFCA) shows unruptured aneurysm in left internal carotid artery (ICA) bifurcation (arrow). B) Immediate post-operative computed tomography shows no unusual post-operative findings. C) Post-operative $28^{\text {th }}$ day diffusion magnetic resonance image shows high signal intensity in left insular cortex (arrow). D) Follow-up TFCA reveals severe vasospasm around the left ICA bifurcation (arrow). 
the most common symptoms of the vasospasms on the left side and right side, respectively. The symptoms lasted from two to fourteen days (average about seven days). In four patients, the severity of vasospasm (estimated by measuring the maximum narrowing of the spastic artery compared with the pre-operative TFCA) exceeded $50 \%$. Despite this, these patients seemed to recover better than those with typical hemorrhagic (such as SAH) vasospasm. In all cases apart from one (who the information was missing), a temporary clip was applied to the parent artery during the operation. In spite of the relatively small or medium sized unruptured aneurysms in these cases, multiple clips were used during the operations. There were mild unusual finding in the intraoperative or post-operative period in three cases: One case involved a transient vasospasm around the clipped aneurysm when the aneurysmal sac was punctured after clipping, in another there was a small amount of epidural hematoma on the immediate post-operative $\mathrm{CT}$ (which did not appear to be related to the vasospasm) and the third case had a mild frontotemporal intracerebral hemorrhage with edema. Chemical angioplasty was administered to the four patients with severe vasospasm (above 50\%) and the other two patients were treated with hydration and anti-platelet medication. In all the cases we reviewed, we found good outcomes. In particular, our case VI had a bilateral MCA bifurcation aneurysm and no vasospasm after clipping of the aneurysms in the area of the right MCA bifurcation. However, there were severe delayed post-operative vasospasms (above $50 \%$ ) only in the $\mathrm{M} 1$ and $M 2$ vessels around the clips used for the left MCA bifurcation aneurysm. Interestingly, the left MCA bifurcation aneurysm was similar in size to the right MCA aneurysms but several clips were used. Additionally, more manipulation for the aneurysm when dissecting around of the parent M1 artery was required and longer temporary occlusion was needed.

Table I: Characteristics of the Six Patients Compatible with Our Inclusion Criteria

\begin{tabular}{|c|c|c|c|c|c|c|}
\hline & $\begin{array}{l}\text { Bloomfield et } \\
\text { al., } 1985 \\
\text { CASE I }\end{array}$ & $\begin{array}{c}\text { Kitazawa I } \\
\text { et al., } 2005 \\
\text { CASE II }\end{array}$ & $\begin{array}{l}\text { Kitazawa II } \\
\text { et al., } 2005 \\
\text { CASE III }\end{array}$ & $\begin{array}{c}\text { Paolini et al., } \\
2005 \\
\text { CASE IV }\end{array}$ & $\begin{array}{l}\text { Ours, } \\
2011 \\
\text { CASEV }\end{array}$ & $\begin{array}{l}\text { Ours, } \\
2012 \\
\text { CASE VI }\end{array}$ \\
\hline Sex/Age (year) & $\mathrm{F} / 54$ & $F / 21$ & $F / 63$ & $\mathrm{~F} / 47$ & $\mathrm{~F} / 41$ & $\mathrm{~F} / 61$ \\
\hline An. Location & Rt. MCA bif. & Lt. paraclinoid & Lt. paraclinoid & Rt. MCA bif. & Lt. ICA bif & Lt. MCA bif. \\
\hline An. Size $(\mathrm{mm})$ & 7 & 4 & 5 & 8 & 5 & 6 \\
\hline Spasm Sx. & $\begin{array}{c}\text { Lt. side weakness } \\
\text { Gr. III }\end{array}$ & $\begin{array}{c}\text { Aphasia } \\
\text { Gerstmann SD }\end{array}$ & $\begin{array}{c}\text { Aphasia } \\
\text { Rt. side } \\
\text { weakness IV }\end{array}$ & $\begin{array}{l}\text { Lt. facial droop } \\
\text { Lt. side } \\
\text { weakness IV }\end{array}$ & $\begin{array}{l}\text { Aphasia } \\
\text { Rt. facial } \\
\text { numbness }\end{array}$ & $\begin{array}{c}\text { Aphasia } \\
\text { Mental change }\end{array}$ \\
\hline Sx. Onset (POD) & $9^{\text {th }}$ & $12^{\text {th }}$ & $9^{\text {th }}$ & $28^{\text {th' }}$ & $28^{\text {th }}$ & $10^{\text {th }}$ \\
\hline Sx. Duration (days) & 7 & 14 & 10 & 2 & 5 & 5 \\
\hline Severity (\%) & 25 & 50 & 50 & 25 & 50 & 50 \\
\hline Temporary Clip (hr) & $\begin{array}{l}\text { Unknown } \\
\text { (unknown) }\end{array}$ & $\begin{array}{l}\text { Use } \\
\text { (unknown) }\end{array}$ & $\begin{array}{c}\text { Use } \\
\text { (unknown) }\end{array}$ & $\begin{array}{c}\text { Use } \\
\text { (unknown) }\end{array}$ & $\begin{array}{l}\text { Use } \\
\text { (3) }\end{array}$ & $\begin{array}{l}\text { Use } \\
(10.5)\end{array}$ \\
\hline Clip No. & 2 & 1 & 2 & 2 & 2 & 3 \\
\hline $\begin{array}{l}\text { Unusual intraoperative } \\
\text { event }\end{array}$ & $\begin{array}{l}\text { When clipped } \\
\text { An. puncturing, } \\
\text { MCA focal } \\
\text { spasm } \\
\text { revealed, } \\
\text { transiently }\end{array}$ & No & No & No & No & No \\
\hline $\begin{array}{l}\text { Unusual post-operative } \\
\text { CT finding }\end{array}$ & No & No & Mild EDH & $\begin{array}{l}\text { Rt. F-T ICH } \\
\text { with brain } \\
\text { swelling }\end{array}$ & No & No \\
\hline Treatment modality & $\begin{array}{c}\text { Hydration } \\
\text { Dexamethasone } \\
4 \mathrm{mg} / \mathrm{hr} \text { for } \\
5 \text { days }\end{array}$ & $\begin{array}{c}\text { Chemical } \\
\text { angioplasty } \\
\text { Triple H }\end{array}$ & $\begin{array}{c}\text { Chemical } \\
\text { angioplasty } \\
\text { Triple H }\end{array}$ & $\begin{array}{l}\text { Hydration } \\
\text { Antiplatelet }\end{array}$ & $\begin{array}{l}\text { Hydration } \\
\text { Antiplatelet } \\
\text { Chemical } \\
\text { angioplasty }\end{array}$ & $\begin{array}{l}\text { Hydration } \\
\text { Antiplatelet } \\
\text { Chemical } \\
\text { angioplasty }\end{array}$ \\
\hline Recovery & $\begin{array}{c}\text { Partially } \\
\text { Lt. side } \\
\text { weakness Gr. 4+ }\end{array}$ & Fully & Fully & Fully & $\begin{array}{l}\text { Partially } \\
\text { minimal } \\
\text { aphasia }\end{array}$ & $\begin{array}{l}\text { Partially } \\
\text { minimal } \\
\text { aphasia }\end{array}$ \\
\hline
\end{tabular}

An, aneurysm; Sx, symptoms; No, number; Lt, left; Rt - right; Gr, grade; $\mathbf{m i n}$, minute; EDH, epidural hematoma; POD, postoperative day; bif, bifurcation. 


\section{DISCUSSION}

Vasospasm with SAH is rarely reported two weeks after rupture of an aneurysm (5). Most of the previous literature has focused on blood breakdown derivatives and their role (2). However, this cannot explain the delayed vasospasm after an uncomplicated operation for UIAs. Some authors have reported postoperative vasospasms after operation for an UIA, but most of these were related to direct vessel injury, surgeryinduced SAH or secondary cerebral arterial constriction due to direct hypothalamic injury during the operation. The injury to the hypothalamus can cause non-hemorrhagic vasospasms but it occurs soon after thalamic injury or injury to the related artery such as anterior communicating artery and it usually lasts a few hours $(1,12)$. For examples, reports written by Peerless and Fein in 1980 are like those $(4,10)$.

Both our cases and previous cases review enabled us to assess the likely causes of delayed non-hemorrhagic vasospasm arising after an uncomplicated operation for UIA. The variable intrinsic characteristics of UIA, such as ongoing enlargement or change of shape play some role in the vasospasm. In 1983, Friedman described a case if vasospasm with an untreated and unruptured posterior-communicating artery aneurysm that showed ongoing enlargement (7). Mechanical stress, such as endothelium distension due to enlargement of the aneurysm, clipping, and manipulation of the sac to dissect adhesion can irritate the vulnerable endothelium of an aneurysm (11). In 1985, Bloomfield and Sonntag reported the first case with MCA aneurysm that showed a true non hemorrhagic postoperative vasospasm of symptomatic and angiographic significance after a delay period (3). In addition to impaired vascular endothelial function, we suggest another possible cause of delayed post-operative non hemorrhagic vasospasm involving the trigemino-cerebrovascular system (TCVS). Continuous stimulation of the TCVS that was brought about by products derived from blood breakdown or mechanical damage (due to spontaneous aneurysm enlargement, manipulation of vessels during application of temporary clips or dissection of the aneurysmal dome) may lead to a delayed depletion of vasodilatory substances (9).

Kitazawa reported 2 cases of post-operative delayed nonhemorrhagic vasospasm with neurological symptoms that were compatible with our criteria among 30 patients with paraclinoid carotid aneurysm. The number of clips used $(p<0.04)$ and temporary occlusion of the ICA $(p<0.05)$ were found to be statistically significant determinants (8).

In 2005, Paolini et al. described one patient who met our inclusion criteria. The patient underwent uncomplicated surgery for UIA located in the MCA bifurcation. Twentyeight days after the operation, the patient developed a left lower facial droop and upper extremity weakness and was treated with hydration and anti-platelet therapy. The patient responded with full recovery of neurological deficits (9).

\section{CONCLUSIONS}

We speculated the multi-factorial mechanisms that may trigger the delayed vasospasm after uneventful clipping for UIAs, such as chemical stimuli (i.e. blood breakdown products) and mechanical stress to the arterial walls around the aneurysm. For clipping of UIAs, it should be kept in mind that neurological symptoms are caused by delayed cerebral vasospasm, and careful observation with proper conservative treatment are necessary to ensure favorable outcomes.

\section{REFERENCES}

1. Arienta C, Balbi S, Caroli M, Fumagalli G: Depletion of calcitonin gene-related peptide in perivascular nerves during acute phase of posthemorrhagic vasospasm in the rabbit. Brain Res Bull 27:605-609, 1991

2. Asano T,Tanishima T, Sasaki T, Sano K: Possible participation of free radical reactions, initiated by clot lysis in the pathogenesis of vasospasm after SAH. In: Wilkins RH (ed), Cerebral arterial spasm: Proceedings of the second international workshop. Amsterdam: Williams \& Wilkins, 1979:190-201

3. Bloomfield SM, Sonntag VK: Delayed cerebral vasospasm after uncomplicated operation on an unruptured aneurysm: Case report. Neurosurgery 17:792-796, 1985

4. Fein JM: Unruptured aneurysms and cerebral vasospasm. In: Wilkins RH (ed), Cerebral Arterial Spasm: Proceedings of the Second International Workshop on Cerebral Vasospasm. Baltimore: Williams and Wilkins, 1980: 499-504

5. Findlay J: Cerebral vasospasm. In: Winn HR, Youmans JR (eds), Youmans Neurological Surgery. 5th ed. Philadelphia, Pa: WB Saunders, 2004:1839-1864

6. Fisher CM, Kistler JP, Davis JM: Relation of cerebral vasospasm to subarachnoid hemorrhage visualized by computerized tomographic scanning. Neurosurgery 6:1-9, 1980

7. Friedman $\mathrm{P}$, Gass $\mathrm{HH}$, Magidson M: Vasospasm with an unruptured and unoperated aneurysm. Surg Neurol 19:2125, 1983

8. Kitazawa K, Hongo K, Tanaka Y, Oikawa S, Kyoshima K, Kobayashi S: Postoperative vasospasm of unruptured paraclinoid carotid aneurysms: Analysis of 30 cases. J Clin Neurosci 12:150-155, 2005

9. Paolini $S$, Kanaan $Y$, Wagenbach A, Fraser K, Lanzino G: Cerebral vasospasm in patients with unruptured intracranial aneurysms. Acta Neurochir (Wien) 147:1181-1188; discussion 1188,2005

10. Peerless S: Postoperative cerebral vasospasm without subarachnoid hemorrhage. In: Wilkins RH (ed), Cerebral Arterial Spasm: Proceedings of the Second International Workshop on Cerebral Vasospasm. Baltimore: Williams and Wilkins, 1980: 496-498

11. Roux S, Loffler BM, Gray GA, Sprecher U, Clozel M, Clozel JP: The role of endothelin in experimental cerebral vasospasm. Neurosurgery 37:78-85; discussion 85-76, 1995

12. Wilson JL, Feild JR: The production of intracranial vascular spasm by hypothalamic extract. J Neurosurg 40:473-479, 1974 